\title{
Directional Selection of Phakopsora pachyrhizi Towards Site-Specific Fungicides in Mato Grosso State
}

\author{
Erlei Melo Reis ${ }^{1}$, Laércio Zambolin ${ }^{2} \&$ Wanderlei Dias Guerra ${ }^{3}$ \\ ${ }^{1}$ Instituto AGRIS, Passo Fundo, RS, Brazil \\ ${ }^{2}$ Bioagro, Universidade Federal de Viçosa, Viçosa, MG, Brazil \\ ${ }^{3}$ Aprosoja/MT, Centro Político Administrativo, Cuiabá, MT, Brazil \\ Correspondence: Erlei Melo Reis, Instituto AGRIS, Rua Miguel Vargas, 291 Passo Fundo, RS, CEP: 99025-380, \\ Brazil. E-mail: erleireis@upf.br
}

Received: March 18, 2021

doi:10.5539/jas.v13n6p100

\author{
Accepted: April 21, $2021 \quad$ Online Published: May 15, 2021 \\ URL: https://doi.org/10.5539/jas.v13n6p100
}

\begin{abstract}
This review focus on the sensitivity reduction of Phakopsora pachyrhizi to site specific fungicides in the Brazilian state of Mato Grosso.The soybean grown area in this state in the 2018/19 growing season was 9,756,668 hectares. The main crop disease is Asian soybean rust that depending on disease severity may cause $80 \%$ yield reduction. The rust chemical control started in the 2002/003 season with site-specific fungicides applied solo and with 3.6 sprayings/ha/season. For these reasons, the fungus had sensitivity reduction to the fungicides DMIs, QoIs and SDHIs resulting in a short effective life. Anti-resistance strategies were not adopted to prevent or delay the development of soybean rust resistant population to site-specific fungicides. Reduced sensitivity to the target site has been observed for all site-specific fungicides involving cross and multiple resistance resulting in ineffective control. So far, eight mutations in Phakopsora pachyrhizi have been identified conferring reduced sensitivity to DMIs, QoIs and SDHIs but so far specific mutations are not considered in chemical control. The directional selection has occurred and has been aggravated season-after-season by the continuous use of site-specific fungicides in a large area, for 18 season and with more than three sprayings/area/season. The presence of soybean weed in one million hectares of cotton crop infected by rust aggravates the directional selection. Anti-resistance strategies should include sowing at the beginning of the recommended season, avoid the December season and replacing it by February, use of scientific criteria to time the first application and the use of multisite fungicides in all applications and in the entire area cultivated with soybean.
\end{abstract}

Keywords: Asian soybean rust, chemical control, Glycine max, sensitivity reduction, site-specific fungicides

\section{Introduction}

In Brazil, soybean [Glycine max (L.) Merr.] is grown from Rio Grande do Sul to the far north, in Roraima, from the West in Rondônia, to the East in Maranhão, extending the growing season and the period of the green plants presence in the field throughout the years. In Mato Grosso (MT) state the cultivated area in the 2019/20 season was 9.85 million ha (IMEA, 2020).

Asian soybean rust (ASR) caused by Phakopsora pachyrhizi (Henning, 1903; H. Sydow \& P. Sydow, 1914) was first described in Japan in 1902 (Henning, 1903). Therefore, since 2007, the disease is present in all places where soybean is grown in the world.

The first report in South America was made in February 2001, in Paraguay (Morel, 2001; Yorinori et al., 2002). In 2002, the disease presence was described in southern Brazil (Reis et al., 2002). At the beginning the disease was found in the south of the country and afterwards it reached the states of the southeast (São Paulo, Minas Gerais), the center-west (Mato Grosso and Goiás) and the northeast (Bahia) (Yorinori et al., 2005).

The Asian soybean rust (ASR) spread was very fast throughout the world and in the American continent. The main reason is that the fungus has very high sporulation rate (Melching et al., 1975), dry light spores and from mature uredia are blown away by the air currents (Caldwell \& Laing, 2005). 
According to Christiano and Scherm (2007), the wind dispersion of the P. pachyrhizi uredospores occurred at an average rate of 8.8 and $10.4 \mathrm{~km} /$ day in the 2005 and 2006 seasons, respectively.

The disease is aggressive causing significant damages to soybean yield. The damage is dependent of the environment and can be appraised in commercial field using the damage functions developed by Danelli et al. (2013).

In general, other rusts such winter rusts have a narrow host range and some showing specificity to cultivars. However, P. pachyrhizi is reported on over more than 150 species all belonging to the Fabaceae family (Slaminko et al., 2008).

The first attempt to control of ASR in the country was the breeding of genetic resistant cultivars. However, after three to five seasons of their introduction, it was found that the fungus was able to infect the new commercial cultivars released as resistant. It was known that the fungus $P$. pachyrhizi has high genetic variability overcoming all cultivars with genetic resistance (Godoy \& Arias, 2003).

ASR control: The remaining measures to control the disease are chemical control and cultural practices such as escape by early season seeding (Mochko et al., 2018; Zambolim et al., 2019).

The control recommendation was mainly the use of fungicides with site-specific mechanisms of action, with emphasis on demethylation inhibitors (DMIs) from the triazole chemical group. However, due to the large number of sprayings of the same active ingredient, researchers, and farmers mainly from the Midwestern states, Mato Grosso and Goiás, already in the 2007/08 season, observed ASR control failure (Silva et al., 2008). This fact was reported in other soybean producing states and regions, with the DMI fungicides and soon after with the quinone outside inhibitor (QoI) and their mixtures (Reis et al., 2015).

Lately, failure in disease control has also been reported in the group of carboxamide fungicides, the succinate dehydrogenase inhibitors (SDHIs) (Simões et al., 2008; FRAC, 2017). These reports confirm the occurrence of cross and multiple resistance of $P$. pachyrhizi to the site-specific mechanism of action (MOA) fungicides used to ASR control (DMI, QoI, SDHI).

Today has been shown that the fungicides DMIs and QoIs, have 40\% maximum ASR control (Reis et al., 2021). The overuse of site-specific fungicides increased the selection pressure in the fungus population in selecting resistant mutants. Therefore, for more than 16 years, selection pressure has occurred in the soybean millions of hectares that received thousands of applications of site-specific fungicides in soybean fields season after season. The rapid adaptation of P. pachyrhizi to DMIs in less than a decade from the beginning of its use for rust control, is therefore attributed to the selection pressure due to its use in large area, a high number of sprayings/area, as well as the clonal dikaryotic fungus life cycle and short generation (Schmitz et al., 2014).

\section{Mutations in Phakopsora pachyrhizi}

After the use of DMI solo for 6-7 seasons with 3-4 sprayings per hectare the first genetic mutation in the population of $P$. pachyrhizi were detected in samples collected in the 2010/11season. The mutation indicated an overexpression of the CYP51 gene associated with reduced fungus sensitivity to DMI (Schmitz et al., 2014).

Subsequently, from samples collected in the 2012/2013 and 2013/2014 seasons, mutations were detected in position F129L resulting in reduced sensitivity to QoIs (Klosowski et al., 2016). All samples analyzed, from the 2013/14 season, from different regions of Brazil, showed the F129L mutation present at different frequencies. The samples from Mato Grosso showed a frequency greater than $90 \%$ in $83 \%$ of the analyzed samples.

The first mutation linked to reduced sensitivity of P. pachyrhizi to SDHI fungicides was detected in the 2015/2016 season. A mutation was identified in the Sdh-C gene (substitution of amino acids in region C, I86F) turning the fungus mutants less sensitive to SDHIs (Simões et al., 2018).

The mutations detected over the years in the P. pachyrhizi population, first for the QoIs: F129 L, later on the DMI: F120L, Y131F/H, K142R, I145F, I475T and recently on the SDHI: C-I86F and C-N88S (Corteva/FRAC, verbal information).

The identification of P. pachyrhizi mutants that occur in Brazil has been perfomed in Germany, Switzerland and in the United States laboratories.

\section{The Sprayed Area Extension and Number of Sprays on the Directional Selection}

The larger the sprayed area with site-specific fungicide, the greater the potential for mutations. For example, the directional selection pressure is proportional to the spore population. Hence, the fungus is highly prone to 
mutations in 36 million hectares of annually cultivated soybean than in smaller areas such those conducted on farm trials sown in a period when it does not enter the soybean-free period (Reis et al., 2020).

The mutations occurred spontaneously during the main growing season (September to May) where most of soybeans are grown in MT and where should be the origin of the problem and where efforts must be concentrated to reduce the evolution of $P$. pachyrhizi sensitivity reduction to site-specific fungicides.

The site-specific fungicides with 3.6 sprays per area in a large area has resulted in evolution of P. pachyrhizi sensitivity reduction to site-specific fungicides appointed as the main reason for reducing control efficacy (Reis et al., 2021).

\section{Cross and Multiple Resistance Among Site-Specific Fungicides}

The evolution of the sensitivity reduction of the ASR control by the site-specific fungicides has been noticed by growers, in field experiments, in in vivo and in vitro tests in the laboratory and finally by the mutation identification. These tests showed the presence of cross and multiple resistance of $P$. pachyrhizi to DMIs (cyproconazole, prothioconanazole, tebuconazole), QoIs (azoxystrobin, picoxystrobin, pyraclostrobin, trifloxistrobin), and SDHIs (benzovindiflupyr, bixafen, fluxapiroxad), worsening the control reduction (Schmitz et al., 2014; Klosowski et al., 2016; Simões et al., 2018).

\section{The Fungicide Sales Pressure}

Other fact faced by soybean producers in MT is the pressure from resellers to use site-specific fungicides, with multiple and cross-resistance, in the ASR control. The resale recommendations do not consider the anti-resistance strategies against $P$. pachyrhizi or the disease cultural control. Related to this fact, the resellers present financing models where the farmers are led to accept their product recommendations, almost from the same supplier line, which are not necessarily the most appropriate.

\section{Ministry of Agriculture and FRAC Actions}

After the commercial launch of the first SDHI in Brazil, March 2014, its use increased exponentially not only in MT, but throughout the country, which resulted in the 2015/16 season, in several cases of control failure, in several regions, especially in southern Brazil. The situation was so worrying that the Ministry of Agriculture, Livestock and Supply (MAPA), through the Department of Plant Health, held a meeting in October 2017, where the problems related to sensitivity reduction were discussed. Due to the problem, the FRAC held a global meeting to discuss the situation of $P$. pachyrhizi control failure evolving all site-specific fungicides (DMI, QoI, and SDHI). FRAC released a recommendation limiting the number of SDHI applications and spraying intervals (FRAC, 2019). These meetings show that there was a late FRAC and MAPA action to solve the problem.

These facts are indicative that something was not correct (high-risk site-specific used solo) related to those fungicides timing which may have contributed to the efficiency reduction in such a short time.

Therefore, Brazilian producers should not, and cannot be responsible for the control reduction by site-specific fungicides recommended for ASR control.

\section{Current Fungicide Efficacy}

When analyzing the result of fungicide efficacy to control ASR in the last season, there was a strong control reduction by the current used fungicides site-specific in double or triple co-formulation (Reis et al., 2021). The trend is the efficacy reduction season after season by site-specific fungicides.

\section{The Limitation of Soybean Seeding Time}

The proposed change in soybean planting of December for February is supported on the following facts:

(a) In the February sown soybean (FSS) plants face a short photoperiod resulting in shorter plant cycle, shorter plant high, smaller leaf area index than those of normal season and of December sown soybean (DSS).

(b) FSS may replace those from the end of December, which since 2015 have received up to 10 sprayings of double or triple site-specific co-formulated fungicides with low control efficacy and where the pathogen spore population is subject to great directional selection.

(c) The FSS experimental areas in the last two seasons showed less rust severity and better control efficiency compared to DSS. The use of multisite fungicides solo or associated to site-specific adopted in the research carried out in 2020 should be the recommendation for use in future FSS. Reduced sensitivity, or mutations, only occur for site-specific (DMI, QoI, SDHI) used solo or in mixes among them (Hollomon, 2015). When applying in tank mixtures or in ready co-formulations of site-specific + multisite mutations do not occur. 
(d) FSS result in a fewer leaf wetting periods required for infection, due to reduced rain frequency. Decreasing the wet period number reduces infection frequency.

(e) Soybean free-period. Zambolim (2019) pointed out as Aprosoja MT argues that the most important phytosanitary measure is the absence of soybean green plants during the soybean free-period. In MT State, the soybean free-period lasts 92 days and the FSS are harvested before the date of its beginning. At the time of FSS harvesting there are no more soybean fields in the state and the predominant air mass at this time of year is probably the Atlantic Polar Mass with winds coming from the south pole towards the Western Amazon, passing through MT. These air currents locally called 'coldness' do not find green infected soybean plants to remove and spread rust spores. Therefore, it cannot be stated that experimental areas carried out in February or even those that would be carried out in the future will be an inoculum source for the future soybean fields. First, due to the fact that the selection pressure exerted on the fungus population occurs mainly during the normal season both because of the large area and use of site-specific fungicides; secondly, by the use of associated multisite fungicides and; thirdly, by the observance of the soybean free-period in FSS.

\section{Impact of Mutations on Phakopsora pachyrhizi}

Considering data from 13 seasons since 2006/07 to 2018/19, experiments coordinated by Embrapa Soja/Ati-rust Consortium, although with the presence of several mutations in this period none of them were specifically identified reducing production contrary to what has been hypothesized.

So far, eight mutations have been detected in P. pachyrhizi, resulting in reduced sensitivity to all site-specific fungicides. However, in work carried out in the field or in the laboratory the mutations presence is not considered just the fungus-reduced sensitivity. So far, no reports were found on which specific mutation out of eight has the greatest impact on soybean yield.

\section{The Environment in Mato Grosso and Soybean Rust}

Some reports cite that in Brazil there are no environmental restrictions for the development of ASR during seasons (Del Ponte et al., 2006; Li et al., 2010). Moreover, according to Lana et al. (2018) there would be no restrictions even for the survival of P. pachyrhizi throughout the year. However, in contrast in all regions of MT the survival of the fungus may be limited by the water deficit over the soybean free-period, June to August, totaling just $36.0 \mathrm{~mm}$ rain (Figure 1) (http://mundogeo.com/2019/08/20).

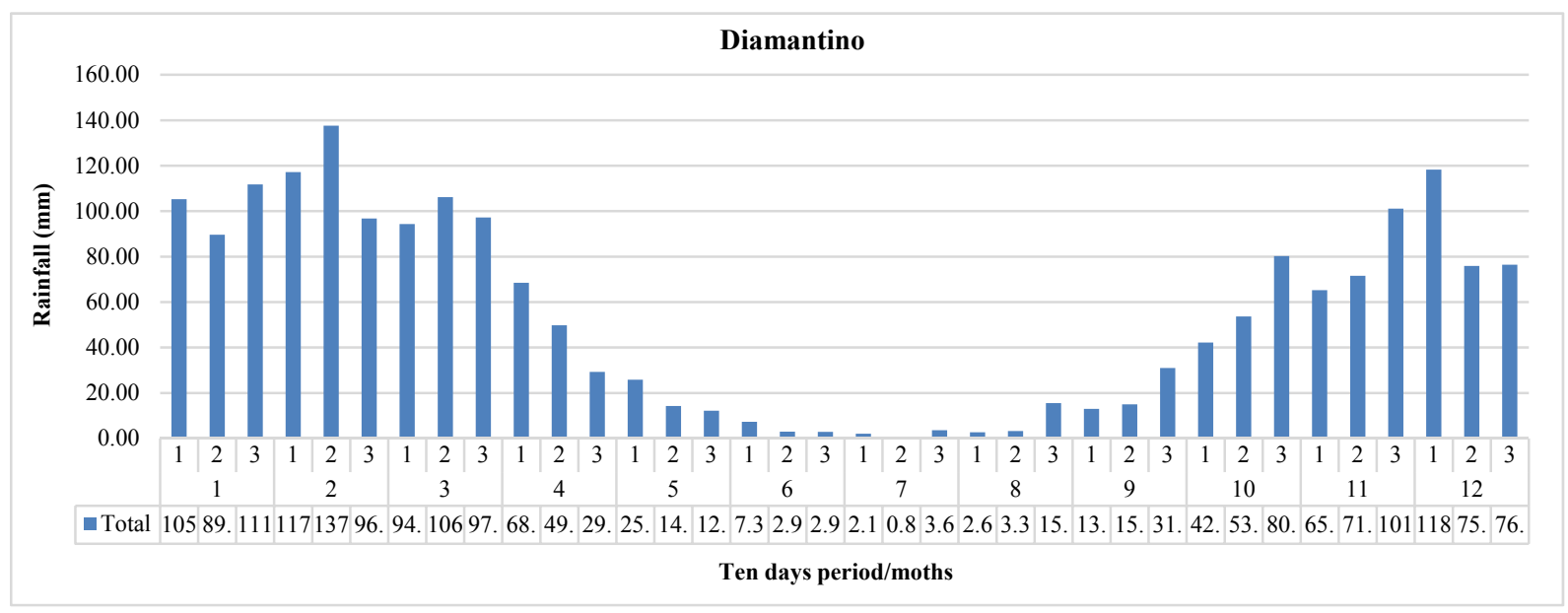

Figure 1. Annual monthly rainfall (mm), in ten days period from 1995 to 2019, in Diamantino county, MT Source: INMET (2020) (latitudee: $14^{\circ} 24^{\prime} 11^{\prime \prime}$ South, longitude: 56 25'37" West, and. altitude $344 \mathrm{~m}$ a.s.1.).

As Zambolim et al. (2019) point out the favorable environment to the ASR epidemic are light and constant rain satisfying the daily wetting period $>8 \mathrm{~h}$ and temperatures $20-25{ }^{\circ} \mathrm{C}$. It is likely that such environmental conditions favorable to disease and fungus should not occur during the soybean free-period, in MT.

Starting on March/April the historical series shows that rainfall starts decreasing throughout the state reducing the rainfall frequency and volume resulting in few periods of continuous leaf wetting to $P$. pachyrhizi complete the infectious process (Melching et al., 1989). The requirement for leaf wetting is hardly satisfied from June to August 
except under irrigation. Under conditions of low relative humidity, low soil moisture, little green vegetation covering the soil, narrow thermal amplitude, dew hardly should occur in MT.

Moreover, according to Isard et al. (2006) findings, P. pachyrhizi uredospores may lose their viability due to the little incidence solar irrradiation during the soybean free-period.

\section{The Origin of Phakopsora pachyrhizi Inoculum in Mato Grosso}

We did not find in the available literature data on the origin of P. pachyrhizi inoculum that arrives annually in soybean crops in MT. It has been assumed that the primary inoculum originates from volunteer plants from local or regional areas and from other host plants (Lana et al., 2018). However, no study has yet been conducted showing which are the predominant inoculum source that ensures the primary inoculum that arrives each season in the soybean farms in MT. A research priority is to quantify the local area and soybean plants density infected by rust as primary inoculum in the state and thus enforce measures to eliminate those foci.

One hypothesis is that the P. pachyrhizi uredospores would reach soybean crops in MT coming from the irrigated soybean in floodplains areas in Tocantins state where part of the crop is harvested at the time when soybeans has already been or is being sown in MT.

In addition, a final hypothesis is that uredospores have viability maintained in the upper atmosphere layers where the temperature reaches several degrees below zero similarly to what has been described for the uredospores of Puccinia graminis Pers. f. sp. tritici Henn, the wheat stem rust (Nagarajan et al., 1976). However, this finding conflicts with the lethal effect of sun irradiation on spores viability as reported by Isard et al. (2006) and Nicolini et al. (2010).

\section{Dissemination of the Inoculum}

As previously reported the $P$. pachyrhizi dry uredospores are transported by the wind and annually may reach soybean crops in Brazil coming from neighboring countries (Yorinori et al., 2005). Bolivia and Paraguay, sow soybeans in the main season (Sept. to Nov.) and in a second season (Feb. to May) in large areas. Therefore, with soybeans vegetating all year around, and the summer the Continental Tropical Air Masses may contribute to spore dispersal from those countries to Brazil, which justify the first rust occurrence in southern Brazil, as reported annually on the Anti-Rust Consortium website. There is also a predominance of Continental Equatorial Mass and Atlantic Equatorial Mass with winds originating in the North and Northeast regions, which certainly contribute to the rust spread to the Brazilian Midwest.

\section{Dynamics in the Phakopsora pachyrhizi Population in the Selection of Resistant Individuals}

In nature, organism populations are composed with different genomes. Therefore, the P. pachyrhizi population is constituted by sensitive and insensitive individuals. As the directional selection is increased by the use of site-specific fungicides solo without considering anti-resistance strategies resistant individuals multiply and sensitive ones are gradually eliminated.

In fungi, there is a mutation rate of one per $10^{6}$ million spores. As an idea of sporulation potential, a soybean plant, severely attacked by rust produces more than 400 million spores (Reis et al., 2018), or 400 mutants/plant.

(a) Supposing that the first P. pachyrhizi uredospores that reached the soybean fields was in the 2019/2020 season in the MT state. This resistant population of the introduced fungus would be considered the F1 generation.

(b) The F1 receives three to four fungicides sprays according to the Anti-rust Consortium (CAF, 2020).

(c) Assuming that at each fungicide spray (considering four applications), a part of the population of $P$. pachyrhizi spores is selected. Thus, after each spraying new resistant generations appear (F2, F3, F4, F5, and Fn) at the end of the normal season considering the fungus seven to 10 days life cycle.

However, in practice the selection for P. pachyrhizi resistance is much more complex and probably the number of resistant mutants would be much high. There is a constant migration of uredospores among soybean fields during the season and a selected spore population for a site-specific fungicide used in the neighboring field when arriving in another field can receive again that same site-specific fungicides pressing further for selection of resistant mutants. The P. pachyrhizi population that escaped the first spray can be spread to neighboring fields where can again receive a second, third and fourth application of the same site-specific fungicide. Therefore, the population would be in F6, F7, F8, Fn generations. When simulating on millions of hectares of soybean sprayed at different times and with the high fungus dispersion, there would be a larger population of resistant individuals. In addition, there is still the possibility of cross and multiple resistance to site-specific fungicides during the seasons a head. 
Considering that late DSS performed since 2015 receiving up to 10 applications of site-specific fungicides (average of 7.4 according to Reis et al., 2020), should result in greater directional selection of resistant spore population and more likely to survive for the next crop season.

On the other hand, considering the statistically lower number of applications and greater efficiency of fungicides in FSS we may infer that FSS, may replace the DSS, and with the possibility of selecting mutant populations may be reduced (Reis et al., 2020). There is an economic and environmental gain, because in addition to the smaller number of applications, it results in a population of the fungus with a lower resistance rate than the current situation, which has lasted for five seasons, resulting from DSS. Although it is possible to select resistant populations in these fields, this does not happen due to the sprayings associated with multisite.

\section{Soybean as Weed in Cotton Crops}

During the DSS there are thousands of cotton hectares where millions of soybean volunteer plants weeds (Pitelli, 2015) growing together. In cotton crops sown in late December and January there are soybean weed plants infected by rust due to environmental conditions favorable to the disease under a high rain frequency and sheltered under cotton plants under ideal microclimate condition for the fungus. The spores that are selected for resistance in DSS are disseminated by the wind to soybean weed plants in the middle of cotton crop. In cotton fields the fungus receive from 6 to 16 new sprays a mean of 7/8 according to IMA (http://imamt.org.br) of the same site-specific fungicides but which indirectly are deposited on soybean weed leaves. Therefore, the situation worsens especially when such weeds plants remain alive within the soybean free-period, as already proven.

Similarly, the directional pressure continues for both DSS and soybean weeds in cotton fields then it is proposed to replace DSS by FSS.

Therefore, it is likely that the population resulting from DSS will have a greater number of sensitive spores to fungicides than those produced in FSS due to the use of multisite throughout the area and in all applications. In addition, the recommendation for fungicidal use proposed initially for the February experimental areas may be extended to future soybean fields all with the isolated or associated multisite in all applications.

\section{Moment of Rust Onset and the Environment}

The first occurrences of rust in FSS, has been recorded in late March and beginning of April. At this time of year, rainfall frequencies are lower than in January and for this reason, fungicides are more efficient (multisite non penetrant). In addition, the unfavorable environment to the disease does not favor the occurrence of new fungus cycles in similar proportion of DSS. The lower frequency of rainfall reduces the minimum leaf-wetting period $>$ 8 hours on soybean leaves, for the fungus secondary cycles, resulting in a lower rust incidence and severity in FSS, as demonstrated in research conducted in the past season (Reis et al., 2020) the present work also showed the same results. Thus, FSS may contribute to reduce directional selection.

We may infer that in the case of cotton crop next to soybean fields the spores produced in late March and April will not find voluntary soybean plants susceptible in the same way that they would find in January when the wetting duration in cotton leaves is maximum.

\section{Directional Selection $\times$ Preventive, Curative and Eradicant Sprayings}

Another aspect that drives to the emergence of mutants of resistant fungus in the population are the curative applications recommended by chemical companies, where each one recommends its portfolio, with sequential applications of the same site-specific (DMI, QoI, SDHI) fungicide. In these situations, directional selection occurs where some site-specific fungicides become less efficient season-after-season. However, the penetrating-mobile fungicides before the sensitivity reduction has been detected they had a protective, curative, and eradicating action in the ASR control (Godoy \& Canteri, 2004; Reis \& Zanatta, 2016).

FRAC indicates the preventive fungicide application but the rust damage does not depend on the absence or presence of the disease but only of its intensity (Danelli et al., 2015). Such damage functions are available for technical assistants to apply in soybean rust control.

According to FRAC (2019), the selection of resistant individuals in the P. pachyrhizi population increases as the number of curative applications of site-specific fungicides increases. FRAC (2019) mentions that application programs started curatively favor the pressure of continuous selection and accelerate the development of resistant pathogen populations and, therefore, should not be used in fields with high spore populations that happens in late DSS; hence, our proposal is to replace this growing season for February. However, contradicting that statement there is no evidence on the protectant and curative use of fungicides on selection for fungicide resistance. There is no evidence that a protectant spray is good fungicide resistance management (van den Bosch et 
al., 2015). In conclusion, current evidence does not support early or protective treatment being a resistance management tactic.

According to FRAC, the first application must be preventive and under this condition according to science, damage is zero. Then we question how about the second, third and other applications, with rust presence, it will no longer be preventive. Something difficult to be explained by science!

\section{Directional Selection and Multisite Fungicides}

Another important issue in the works carried out by Aprosoja show that the soybean fields carried out in FSS resulted in a statistically significant rust lower incidence than in DSS; where multisite sprayings was used in $100 \%$ of the areas (Reis et al., 2020).

According to Ishii \& Hollomon, (2015) multisite fungicides do not select resistant mutants in the population of phytopathogenic fungi. About more than a half a century have passed, and there are no reports of fungal resistance to multisite fungicides, especially to rust fungi (basidiomycete).

\section{Anti-resistance Strategies}

There are several strategies in the literature, about tactics to avoid/reduce the development of mutants, in the population of phytopathogenic fungi (Zambolim, 2019). However, for ASR, three strategies are effective (a) remove the site-specific fungicide from the market; (b) escape the disease by modify sowing time; and, (c) use of multisite fungicides throughout the area and in all applications. Regarding the sowing time Aprosoja defends this practice considering the results already obtained in field research, proving that there was less ASR incidence and severity in the FSS and with less fungicide applications compared to DSS. Therefore, in the case of ASR in MT multisite fungicides are the main and only efficient tool to improve control when resistance is widespread.

\section{Multisite Fungicides}

Multisite fungicides as the main anti-resistant strategy, started to be widely used to control ASR in 2012/13 season. Results from 2018/19 season, from the experimental areas in network trials coordinated by EMBRAPA (Embrapa Soja, 2018), through the Anti-rust Consortium, showed that chlorothalonil fungicide was the most efficient in mixing with the site-specific fungicides. Similar results were also obtained by Ponce et al. (2018) and Zambolim (2019). Today there are 49 chlorothalonil-based products registered in Ministry of Agriculture website for the control of ASR (MAPA, 2020). However, in addition to chlorothalonil there are alternatives such as mancozeb, copper oxychloride, and Bordeaux mixture (Reis et al., 2019).

\section{Conclusions}

(a) Directional selection to select mutants in the $P$. pachyrhizi population occurs due the use of site-specific fungicides (DMI, QoI, and SDHI) continuously for 18 years.

(b) The risk for resistance development is higher when a large area such as 10 million hectares is sprayed with site-specific fungicides three to six spraying/ha, to control a fungus with high sporulation potential.

(c) Presence of high soybean weed plants population in several crops especially cotton where the fungus receives a great number of site-specific fungicides sprayings increasing directional selection.

(d) There is no record in the available literature of $P$. pachyrhizi mutations towards multisite (chlorothalonil, mancozeb and copper oxychloride) fungicides.

(e) Multisite + site-specific fungicides must be sprayed in all soybean area and in all applications to fight ASR resistance.

(f) Low risk of FSS considers the unfavorable environment to the pathogen.

(g) The slow technology diffusion, the inexpressive number of multisite fungicides sprayings as the main strategy has led to control efficacy reduction with considerable losses to growers.

\section{References}

CAF (Consórcio Antiferrugem). (2020). Moção de Esclarecimento.

Caldwell, P., \& Laing, M. (2005). Soybean rust-A new disease on the move. Plant Disease, 89, 109. https://doi.org/10.1094/PD-89-0109B

Christiano, R., \& Sherm, H. (2007). Quantitative aspects of the spread the Asian soybean rust in the southern United States, 2005 to 2006. Phytopathology, 97, 1428-1433. https://doi.org/10.1094/PHYTO-97-11-1428 
Danelli, A. L. D., Reis, E. M., \& Boaretto, C. (2015). Critical-point model to estimate yield loss caused by Asian soybean rust. Summa Phytopathologica, 41(4), 262-269. https://doi.org/10.1590/0100-5405/2003

Del Ponte, E. M., Godoy, C. V., Canteri, M. G., Reis, E. M., \& Yang, X. B. (2006). Models and applications for risk assessment and prediction of Asian soybean rust epidemics. Fitopatologia Brasileira, 31, 533-544. https://doi.org/10.1590/S0100-41582006000600001

Embrapa Soja. (2020). Eficiência de fungicidas multissitios no controle da ferrugem-asiática da soja, Phakopsora pachyrhizi, na safra 2017/18: Resultados sumarizados dos ensaios cooperativos. Circular Técnica (INFOTECA-E). Retrieved from https://www.infoteca.cnptia.embrapa.br/infoteca/handle/doc/ 1097030

EMBRAPA. (2010). Empresa Brasileira de Pesquisa Agropecuária. Tecnologias de produção de soja região central do Brasil 2011. Londrina: Embrapa Soja: Embrapa Cerrados: Embrapa Agropecuária Oeste.

FRAC (Fungicide Resistance Action Committee). (2017). Informação sobre carboxamidas em ferrugem da soja. FRAC Internacional, Informativo 01/2017, SDHI-Working Group. Retrieved from http://media.wix.com/ ugd/85b1d3_060a6876562140b693f03708057acff2.pdf

FRAC (Fungicide Resistance Action Committee). (2019). Novas recomendações para o manejo da ferrugem asiática da soja. Retrieved from https://www.frac-br.org/ recomendacoes-ferrugem-asiatica-da-

Godoy, C. V., \& Arias, C. A. A. (2003). Resistência quebrada. Cultivar, 5(55), 28-29.

Godoy, C. V., \& Canteri, M. G. (2004). Efeitos protetor, curativo e erradicante de fungicidas no controle da ferrugem da soja causada por Phakopsora pachyrhizi, em casa-de- vegetação. Fitopatologia Brasileira, 29, 097-101. https://doi.org/10.1590/S0100-41582004000100016

Hartman, G. L., Rupe, J. C., Sikora, E. J., Domier, L. L., Davis, J. A., \& Steffey, K. L. (2015). Compendium of soybean diseases and pests (p. 201). The American Phytopathological Society, St. Paul, Minesota, USA.

IMA (Instituto Mato-grossense do Algodão). (2020). Esclarecimentos técnicos sobre soja "tiguera" na cultura do algodoeiro em Mato Grosso-Comunicado $N^{o}$ 001/2020. Retrieved from https://imamt.org.br/imamt-fazesclarecimentos-tecnicos-sobre-soja-tiguera-no-algodao

IMEA (Instituo Mato-grossense de Economia Agropecuária). (2020). Estimativa da Safra de Soja-2019/20 (4th ed.).

INMET (Instituto Nacional de Meteorologia). (2020). BDMEP-Banco de Dados Meteorológicos para Ensino e Pesquisa. Retrieved from http:/www.inmet.gov.br/portal/index.php?r=bdmep/bdmep

Isard, S. A., Dufault, N. S., Miles, M. R., Hartman, G. L., Russo, J. M., De Wolf, E. D., \& MoreL, W. (2006). The effect of solar irradiance on the mortality of Phakopsora pachyrhizi urediniospores. Plant Disease, 90, 941-945. https://doi.org/10.1094/PD-90-0941

Ishii, H., \& Hollomon, W. (2015). Fungicide resistance in plant pathology (p. 490). Japan: National Institute for Agricultural Environmental Sciences. https://doi.org/10.1007/978-4-431-55642-8

Klosowski, A., May-De Mio, L., Miessner, S., Rodrigues, R., \& Stammler, G. (2015). Detection of the F129L mutation in the cytochrome b gene in Phakopsora pachyrhizi. Pest Management Science, 72(6), 1211-5. https://doi.org/10.1002/ps.4099

Li, X., Esker, P. D., Pan, Z., Dias, A. P., Xue, L., Yang, X. B. (2010). The uniqueness of the soybean rust pathosystem: An improved understanding of the risk in different regions of the world. Plant Disease, 94, 796-806. https://doi.org/10.1094/PDIS-94-7-0796

MAPA (Ministério da Agricultura, Pecuária e Abastecimento). (2020). Sistema de Agrotóxicos Fitossanitário-AGROFIT (Consulta Aberta). Retrieved from http://agrofit.agricultura.gov.br/agrofit_cons/ principal_agrofit_cons

Melching, J. S., Bromfield, D. K. R., \& Kingsolver, C. H. (1975). Infection, colonization and uredosporos production on Wayne soybean by four cultures of Phakopsora pachyrhizi. Phytopatjology, 65, 822-823.

Melching, J. S., Dowler, W. M., Koogle, D. L., \& Royer, M. H. (1989). Effects of duration, frequency, and temperature of leaf wetness periods on soybean rust. Plant Disease, 73(2), 17-122. https://doi.org/ 10.1094/PD-73-0117 
Mochko, A. R., Zambolim, L., \& Parreira, D. F. (2019). Phosphate fertilization reduces the severity of asian soybean rust under high disease pressure. Journal of Agricultural Science, 11, 261-273. https://doi.org/ 10.5539/jas.v11n1p261

Morel, W. (2001). Roya de la soja. Comunicado técnico-Reporte oficial (Serie Fitopatológica $\mathrm{n}^{\mathrm{0}} 1$ - Juño de 2001). Ministerio de Agricultura y Ganaderia. Subsecretaria de Agricultura. Dirección de Investigación Agrícola. Centro de Investigación Agrícola (CRIA), Capitán Miranda, Itapúa, Paraguay.

Nagarajan, S., Singh, H., Joshi, L. M., \& Saari, E. E. (1976). Meteorological conditions associated with long-distance dissemination and deposition of Puccinia graminis tritici uredospores in India. Phytopathology, 66, 198-203. https://doi.org/10.1094/Phyto-66-198

Nicolini, F., Reis, E. M., Zoldan, S. M., Danelli, A. D., Zanatta, M., Avozani, A., ... Garces, F. R. (2010). Effect of solar irradiation on the Phakopsora pachyrhizi uredospores germination. XLIII Congresso Brasileiro de Fitopatologia, 2010, Cuiabá. Tropical Plant Pathology-Suplementos (Vol. 35, p. S143). São Paulo: Tecart.

Pitelli, R. A. (2015). O termo planta-daninha. Planta Daninha, 33(3). https://doi.org/10.1590/S0100-835820150 00300025

Ponce, R. B. O., Zambolim, L., Fortunato, A. A., \& Queiroz, L. F. (2018). High risk fungicides combined to low risk can be a new strategy for management of Asian Soybean Rust at the beginning of the epidemic. Journal of Agricultural Science, 11, 149-158. https://doi.org/10.5539/jas.v11n1p149

Reis, E. M., \& Zanatta, T. (2016). Curative and eradicant action of fungicides to control Phakopsora pachyrhizi in soybean plants. Summa Phytopathologica, 42(4), 295-302. https://doi.org/10.1590/0100-5405/2180

Reis, E. M., Casa, R. T., \& Michel, C. (2002). Ocorrência de epidemia da ferrugem da soja no Rio Grande do Sul na safra 2001/2002. Fitopatologia Brasileira, 27(SP), S198.

Reis, E. M., Pasquali, R. M., Belufi, L. M. R., Guerra, W. D., \& Zanatta, M. (2020). Comparative severity analysis of Asian soybean rust in soybean farms sown in December and February in Mato Grosso, 2018/19 growing season. Journal of Agricultural Science, 12(9), 130. https://doi.org/10.5539/jas.v12n9p130

Reis, E. M., Reis, A. C., \& Carmona, M. A. (2019). Manual de fungicidas: Guia para o controle químico racional de doenças de plantas (p. 259, 8th ed.). Berthier, Passo Fundo.

Reis, E. M., Reis, A. C., \& Zanata, M. (2018). Incidência foliolar como indicador da primeira aplicação de fungicida visando ao controle econômico da ferrugem asiática da soja. Summa Phytopathologica, in press.

Reis, E. M., Reis, A. C., Zanatta, M., Silva, L. H. C. P., Siqueri, F. V., \& Silva, J. R. C. (2017). Evolução da redução da sensibilidade de Phakopsora pachyrhizi a fungicidas e estratégia para recuperar o controle (p. 104, 3rd ed.). Passo Fundo: Berthier.

Reis, E. M., Sartori, A. F., \& Camara, R. K. (2004). Modelo climático para a previsão da ferrugem da soja. Summa Phytopathologica, 30(2), 290-292.

Reis, E. M., Zanatta, M., \& Reis, A. C. (2021). Reduced Asian soybean rust control by commerciaf co-formulations in the 2018-2019 growing season in Southern Brazil. Journal of Agricultural Science, 13(4), 113. https://doi.org/10.5539/jas.v13n4p113

Schmitz, H. K., Medeiros, C. A., Craig, I. R., \& Stammler, G. (2014). Sensitivity of Phakopsora pachyrhizi towards quinone-outside inhibitors and demethylation-inhibitors, and corresponding resistance mechanisms. Pest Management Science, 70, 378-388. https://doi.org/10.1002/ps.3562

Schneider, R. W., Hollier, C. A., \& Whitam, H. K. (2005). First report of soybean rust caused by Phakopsora pachyrhizi in the continental United States. Plant Disease, 89, 774. https://doi.org/10.1094/PD-89-0774A

Silva, L. H. C. P., Campos, H. D., Silva, J. R. C., Ribeiro, G. C., Rocha, R. R., \& Moraes, D. G. (2008). Eficácia reduzida de triazóis no controle da ferrugem asiática. Fitopatologia Brasileira, 33, 228.

Simões, K., Hawlik, A., Rehfus, A., Gava, F., \& Stammler, G. (2018). First detection of a SDH variant with reduced SDHI sensitivity in Phakopsora pachyrhizi. Journal of Plant Diseases and Protection, 125, 21-26. https://doi.org/10.1007/s41348-017-0117-5

Slaminko, T. L., Miles, M. R., Marois, J. J., Wright, L., \& Hartman, G. L. (2008). Hosts of Phakopsora pachyrhizi identified in field evaluations in Florida. Plant Health Progress, 9(1), 6. https://doi.org/ 10.1094/PHP-2008-1103-01-RS 
Sydow, H., \& Sydow, P. (1914). A contribution to knowledge of parasitic fungi of the island of Formosa. Annales Mycologici, 12, 108.

Van den Bosch, F., Pavely, N., Fraaije, B., Van den Berg, F., \& Oliver, R. (2015). Chapter 5. Evidence-Based resistance management: A review of existing evidence. In H. Ishii \& W. D. Hollomon (Eds.), Fungicide resistance in plant pathogen. Principles and guide to practical management (pp. 63-76). Springer Japan. https://doi.org/10.1007/978-4-431-55642-8_5

Yorinori, J. T., Moreli, P. W., Frederick, R. D., Costamilan, L. M., \& Bertagnolli, P. F. (2002). Epidemia de ferrugem da soja (Phakopsora pachyrhizi) no Brasil e no Paraguai, em 2001 e 2002. Fitopatologia Brasileira, 27(SP), S178.

Yorinori, J. T., Paiva, W. M., Frederick, R. D., Costa Milan, L. M., Bertagnolli, P. F., Hartman, G. L., ... Nunes Junior, J. (2005). Epidemics of soybean rust (Phakopsora pachyrhizi) in Brazil and Paraguay from 2001 to 2003. Plant Dis., 89, 675-677. https://doi.org/10.1094/PD-89-0675

Zambolim, L. (2006). Manejo integrado da ferrugem asiática da soja. In L. Zambolim (Ed.), Ferrugem asiática da soja (pp. 73-98). Viçosa: UFV.

Zambolim, L. (2019). Vulnerabilidade no controle químico da ferrugem da soja com o emprego de fungicidas sistêmicos de mecanismo de ação específico. In L. Zambolim (Eds.), O que engenheiros agrônomos devem saber para orientar corretamente o uso de produtos fitossanitários (pp. 326-371). Universidade Federal de Viçosa, Viçosa, Minas Gerais.

Zambolim, L., Mochko, A. R., Parreira, D. F., \& Valadares, S. V. (2019). Potassium fertilization reduces the severity of Asian soybean rust under high disease pressure. Journal of Agricultural Science, 11, 116-129. https://doi.org/10.5539/jas.v11n11p116

\section{Copyrights}

Copyright for this article is retained by the author(s), with first publication rights granted to the journal.

This is an open-access article distributed under the terms and conditions of the Creative Commons Attribution license (http://creativecommons.org/licenses/by/4.0/). 